\title{
Penerapan Model Rapid Application Development (RAD) Dalam Rancang Bangun Sistem Informasi Warga
}

\author{
Ade Suryanto1, M. Ibnu Maliki² \\ ${ }^{1}$ Program Studi Teknik Industri, Universitas Bina Sarana Informatika \\ 2Program Studi Sistem Informasi, Universitas Bina Sarana Informatika \\ *ade.ayo@bsi.ac.id
}

\begin{abstract}
Abstrak
Pada saat ini kemajuan teknologi begitu sangat cepat. Hampir disemua sektor kehidupan memanfaatkan kemajuan teknologi ini. Dari bidang ekonomi, pendidikan, hingga ke bidang pemerintahaan tak terkecuali dengan layanan pemerintah tingkat bawah yaitu Rukun Tetangga yang juga dapat memanfaatkan kemajuan teknologi ini dalam pelayanannya. Di lingkungan RT 007 pelayanan yang dilakukan masih bersifat manual untuk itu akan dilakukan perancangan pembuatan sistem informasi warga yang membantu dalam proses pelayanan. Pembuatan aplikasi website ini menggunakan metode Rapid Application Development dalam pengembangannya dan juga aplikasi ini di bangun menggunakan framework Codeigniter 3 dan Bootstrap yang berbasis website . untuk membangun sistem ini bahasa pemogramman yang digunakan adalah HTML, PHP, Javascript dan CSS. Aplikasi website yang dibangun ini bertujuan dapat mempermudah warga dalam pengajuan surat pengantar, mempermudah dalam memberikan informasi keuangan kas RT, dan juga mempermudah ketua RT dalam pembuatan laporan. Pengujian yang dilakukan aplikasi ini menggunakan Black Box Testing yang berpusat di proses masukkan atau inputan saja.
\end{abstract}

Kata kunci: Codeigniter, Model RAD, Sistem Informasi, Pelayanan Warga, Teknologi

\begin{abstract}
At this time the advancement of technology is so very fast. Almost all sectors of life take advantage of these technological advances. From the fields of economy, education, to the field of government, there is no exception for lower-level government services, namely the Rukun Tetangga who can also take advantage of this technological advancement in their services. In the neighborhood of RT 007, the services provided are still manual, for this reason, a design for the creation of a citizen information system that helps in the service process will be carried out. Making this website application uses the Rapid Application Development method in its development and this application is also built using the Codeigniter 3 framework and website-based Bootstrap. To build this system the programming languages used are HTML, PHP, JAVASCRIPT and CSS. This website application that was built aims to make it easier for residents to submit cover letters, make it easier to share RT cash financial information, and also make it easier for Leader RT to make reports. Tests carried out by this application use Black Box Testing which is centered on the input process or input only.
\end{abstract}

Keywords: Codeigniter, RAD model, Information System, Citizen Services, Technology.

\section{Pendahuluan}

Informasi yang cepat dan akurat saat ini sudah

pelayanan. Apalagi pelayanan tersebut langsung

menjadi hal yang penting dalam proses berhubungan dengan masyarakat, Salah 
satunya adalah pelayanan rukun tetangga. Berdasarkan Peraturan Menteri Dalam Negeri Nomor 5 Tahun 2007 Tentang Pedoman Penataan Lembaga Kemasyarakatan yang berbunyi "Rukun Tetangga, untuk selanjutnya disingkat RT atau sebutan lainnya adalah lembaga yang dibentuk melalui musyawarah masyarakat setempat dalam rangka pelayanan pemerintahan dan kemasyarakatan yang ditetapkan oleh Pemerintah Desa atau Lurah".

Berdasarkan pedoman diatas juga bahwa RT/RW mempunyai fungsi: (a) Pendataan kependudukan dan pelayanan administrasi pemerintahan lainnya; (b) Pemeliharaan keamanan, ketertiban, dan kerukunan hidup antar warga; (c) Pembuatan gagasan dalam pelaksanaan pembangunan dengan mengembangkan aspirasi dan swadaya murni masyarakat; dan (d) Penggerak swadaya gotong royong dan partisipasi masyarakat di wilayahnya.[1]. Jadi salah satu tugas Ketua RT adalah melayani masyarakat dalam cakupan wilayahnya, salah satunya membantu pembuatan surat-menyurat. Pembuatan suratmenyurat biasanya menggunakan blangko atau template surat yang sudah di fotocopy. Warga harus mengisi buku tamu kemuadian mengisi data surat, Ketua RT kemudian mengetik surat berdasarkan data yang telah diberikan, setelah selesai baru menandatangani surat [2].
Di Lingkungan RT 07/04 Kelurahan Jati adalah salah satu lembaga atau instansi yang menjalankan tugas dan fungsi tersebut. Oleh karena itu dalam menjalankan tugas dan fungsinya dibutuhkan pelayanan yang baik dan cepat. Dilingkungan RT 07/04 proses pelayanan yang terjadi masih menggunakan sistem konvensional dimana jika warga ingin membuat surat pengantar harus datang ke rumah Ketua RT untuk minta dibuatkan surat pengantar. Proses pelayanan yang berjalan saat ini juga terhambat oleh keberadaan Ketua RT yang bekerja , jadi untuk pelayanan yang dilakukan harus menunggu ketua RT pulang bekerja. Penggunaan Kas di RT 07/04 yang belum transparansi juga menjadi masalah.

Pengelolaan data dan proses administrasi penduduk di lingkungan RT 07/04 yang masih menggunakan sistem konvensional dalam pelaksanaannya oleh karena itu dalam mempermudah proses pengelolaan data dan administrasi penduduk dibutuhkan suatu sistem informasi yang mendukung kegiatan tersebut. Sistem informasi yang akan dibuat adalah berbasis website yang memudahkan warga dalam pengajuan surat pengantar kapan saja tanpa harus datang ke rumah Ketua RT 07/04. Dengan Sistem Informasi ini warga juga dapat melihat keuangan kas yang ada mulai dari pemasukan hingga pengeluaran. Metode pengembangan sistem informasi yang akan 
digunakan adalah metode Rapid Application Development (RAD).

\section{Tinjauan Pustaka}

\subsection{Penelitian Terkait}

Hasil Penelitian sebelumnya "Tentang Sistem Informasi Dan Administrasi RT (Sipakrt) Berbasis Web dapat membantu mempercepat kegiatan administrasi di tingkat RT"[2]. Pada penelitian lainnya dari artikel "Sistem Informasi Manajemen Pelayanan Masyarakat Tingkat RT dan RW Berbasis Website dengan model Scrum" yang dalam pengembangannya sistem dibangun dengan framework laravel mampu menjangkau hingga cakupan yang lebih luas, yaitu ke tingkat RW sehingga membantu ketua RW dalam mengelola data warganya" [3]. Penelitian berikutnya yaitu artikel "Sistem Informasi warga (SIMWARGA) Tingkat RT dan RW Berbasis Web", yang mana sistem ini di rancang menggunakan model Waterfall, dan mampu memberikan solusi antara lain semua kebutuhan yang berhubungan dengan warga dapat diakomodir secara online, terutama dalam hal paling mendasar yaitu pengelolaan data warga[4]. Pada penelitian lainnya yaitu "Sistem Informasi Pelayanan Administrasi Kelurahan Berbasis Web Dengan Fasilitas E-Complaint Menggunakan Telegram Bot", yang mana sistem • ini dirancang dengan model RAD untuk dipergunakan di lingkungan kelurahan, dimana
Penerimaan pelayanan atau permintaan data di Kelurahan Pogar yang semakin meningkat, sedangkan dengan kecepatan pelayanan adalah faktor utama, maka pendaftaran pembuatan surat keterangan atau pelaporan tentang adanya kejadian secara manual tentu kurang cepat,dan rentan terjadi human error atau kesalahan dari manusia. Dengan adanya sistem ini diharapkan dapat mempermudah dalam pelayanan di Kelurahan Pogar Kecamatan Bangil Kabupaten Pasuruan.[5].

\subsection{Landasan Teori}

\section{Pengertian Website}

"World Wide Web atau lebih sering dikenal sebagai Web adalah suatu layanan sajian informasi yang menggunakan konsep hyperlink (tautan), yang memudahkan para pengguna internet menjelajah dunia maya(internet)".[6][7]. Website terbagi menjadi 3 jenis yaitu:

Web Statis adalah website yang halamanya tidak berubah. Perubahan suatu halaman dilakukan secara manual dengan mengedit kode yang menjadi struktur website tersebut.

Web Dinamis merupakan website yang dibangun secara terstruktur yang diperuntukan untuk dapat diupdate sesering mungkin. Biasanya disediakan halaman Backend untuk proses update.

Web Interaktif adalah website yang dapat berinteraksi dengan penggunanya. Dan biasanya bersifar forum diskusi dan blog. 


\section{Model RAD}

Model Rapid Application Development merupakan salah satu metode pengembangan aplikasi yang menekankan pada siklus perkembangan dalam waktu yang singkat, dan merupakan metode berulang (iterative). [8]. Menurut Sukamto, Metode Pengembangan Perangkat Lunak Rapid Application Development (RAD) adalah model proses pengembangan perangkat lunak yang bersifat incremental terutama untuk waktu pengerjaan yang pendek".[9]. Dengan metodologi RAD dibagi-bagi menjadi beberapa modul dan dikerjakan beberapa tim dalam waktu yang hampir bersamaan dalam waktu yang sudah ditentukan. Model ini melibatkan banyak tim, dan setiap tim mengerjakan tugas yang selevel, namun berbeda sesuai dengan pembagian modul sistem.[10]

\section{Pengertian Sistem Informasi}

Sistem Informasi adalah "suatu sistem yang menyediakan informasi untuk manajemen pengambilan keputusan atau kebijakan dan menjalankan operasional dari kombinasi orangorang, teknologi informasi dan prosedur yang terorganisasi”.[11]

\section{Pengertian Rancang Bangun}

Rancang Bangun merupakan penggambaran, dari perencanaan, dan pembuatan sketsa atau pengaturan dari beberapa elemen yang terpisah kedalam satu kesatuan yang utuh dan berfungsi.
Dengan demikian pengertian rancang bangun merupakan kegiatan menerjemahkan hasil analisa ke dalam bentuk paket perangkat lunak kemudian menciptakan sistem tersebut atau memperbaiki sistem yang sudah ada.[12]

\section{Pengertian PHP}

PHP "merupakan skrip yang dijalankan di server, dimana kode yang menyusun program tidak perlu diedarkan ke pemakai sehingga kerahasiaan kode dapat dilindungi. PHP didesain khusus untuk aplikasi web. PHP dapat disisipkan diantara bahasa HTML dan bahasa serverside".[13]

\section{Metode Penelitian}

\subsection{Tahapan Penelitian}

Metode yang digunakan untuk pengembangan perangkat lunak ini adalah metode Rapid Application Development (RAD), Menurut Sukamto, RAD terbagi kedalam lima tahap, antara lain:[14]

\section{Pemodelan Bisnis}

Pada Tahapan ini dilakukan untuk memodelkan fungsi informasi bisnis yang nantinya akan dibuat. Ditahap ini juga dilakukan pengamatan untuk kebutuhan aplikasi yang dibuat.

\section{Pemodelan Data}

Proses pemodelan data adalah modelkan data apa saja yang dibutuhkan berdasarkan pemodelan bisnis dan mendefinisikan atribut serta relasi antar datanya. Yaitu dengan 
menggunakan Entity Relationship Diagram dan Logical Record Structure.

\section{Pemodelan Proses}

Pada tahap ini, pengimplementasian dilakukan berdasarkan pemodelan bisnis yang sudah didefinisikan terkait dengan pemodelan data. Ditahap ini pembuatan use case dan activity diagram dilakukan.

\section{Pembuatan Aplikasi}

Mengimplementasikan pemodelan proses dan data dilakukan ditahap ini dengan menggunakan bahasa pemogramman yang dipakai yaitu HTML, PHP, Javascript, dan CSS

\section{Pengujian dan Pergantian}

Menguji komponen-komponen yang telah dibuat. Sehingga jika sudah lolos uji maka dapat dilakukan pengembangan ke komponen selanjutnya. Untuk melakukan pengujian dilakukan dengan Black Box Testing.

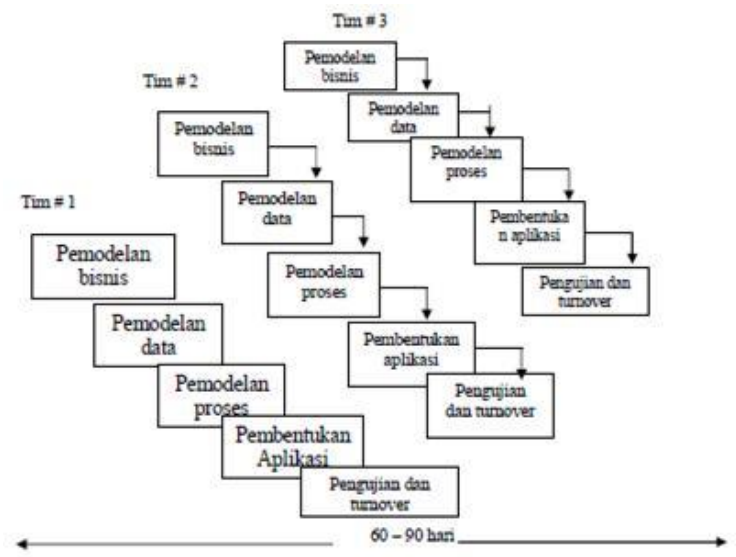

Gambar 1. Model RAD

\subsection{Perancangan dan Desain Aplikasi}

1. Analisa Kebutuhan
Analisa kebutuhan yang diperlukan oleh sistem ini yaitu kebutuhan administrator, user dan penggunaan sistem ini adalah sebagai berikut :

1. Analisa kebutuhan pada bagian administrator atau Ketua RT :

a. Admin dapat melakukan login ke halaman dashboard admin.

b. Admin dapat mengelola data user atau warga seperti menambahkan data warga baru, merubah data warga, mengaktifkan maupun menonaktifkan data warga dan menghapus data warga.

C. Admin juga dapat mengganti profil admin itu sendiri seperti mengganti foto, dan merubah data personal admin.

d. Admin dapat mengelola data kas RT seperti menambahkan kas masuk dan kas keluar.

e. Admin dapat mengelola data pengajuan permintaan surat pengantar seperti memverifikasi permintaan, merubah data permintaan dan menghapus data permintaan.

f. Admin dapat mengelola data pengumuman seperti menambahkan pengumuman baru , merubah pengumuman dan menghapus pengumuman.

g. Admin dapat mencetak laporan sesuai dengan yang ingin dibuatkan laporan

h. contohnya laporan kas masuk, laporan kas keluar dan laporan pengajuan permintaan surat pengantar.

i. Admin dapat melakukan logout dari website. 
Pada Gambar 2, menjelaskan diagram use case, yang menggambarkan kegiatan dari aktor yaitu admin atau pengguna di tingkat teratas. Memiliki ijin akses untuk memanipulasi semua fitur pada sistem aplikasi.

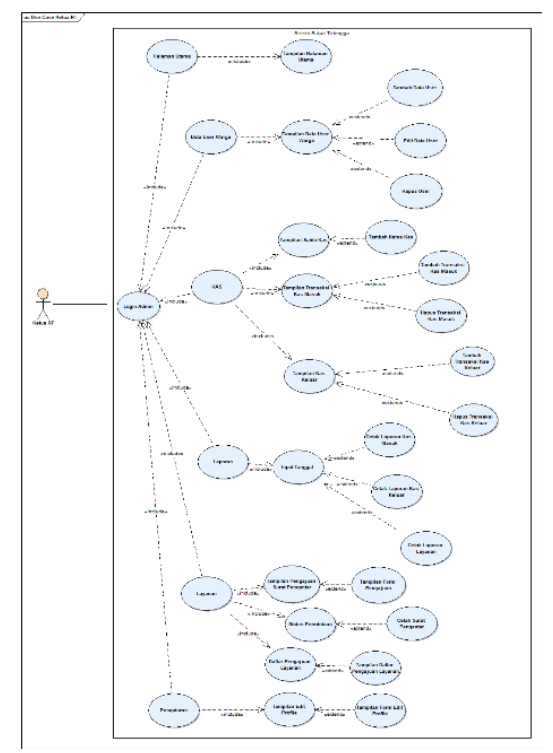

Gambar 2. Diagram Use Case Admin

\subsection{LRS(Logical Relationship Structure)}

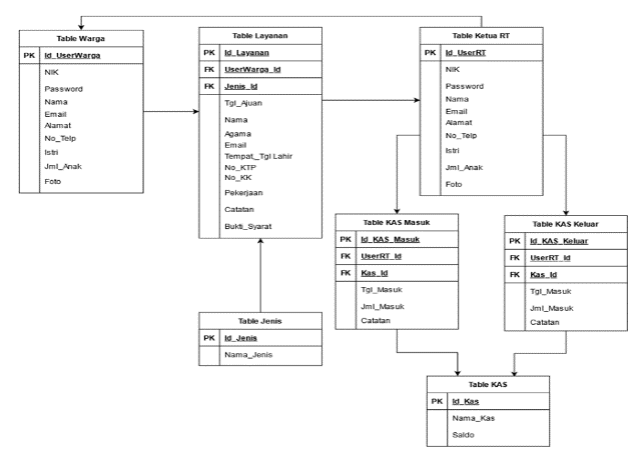

Gambar 4. LRS

Gambar 4 adalah LRS yang mewakili dari deskripsi struktur data sistem yang dibangun. Terdiri dari tabel dengan kolom atau field serta kunci utama atau primary key yang saling berelasi.

\section{Hasil dan Pembahasan}

Pada tahap ini, dibahas mengenai rancangan hasil rancang bangun sistem warga, mulai dari input proses hingga luaran. Berupa form antar muka yang memudahkan para pengguna dalam menggunakan aplikasi.

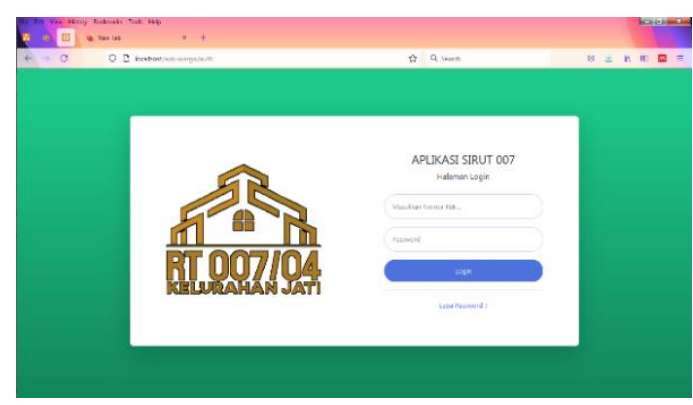

Gambar 5. Form Login

Gambar 5 adalah merupakan form login untuk masuk ke sistem. Tiap pengguna untuk dapat masuk ke dalam sistem aplikasi warga harus melakukan login sesuai level aksesnya masingmasing(admin atau warga).

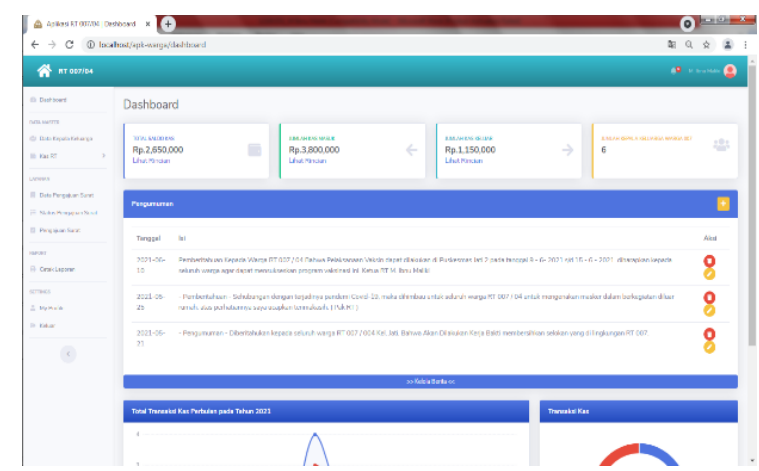

Gambar 6. Dashboard Admin

Gambar 6 diatas adalah antar muka dashboard admin, setelah berhasil login, maka sistem mengarahkan admin ke tampilan dashboard awal atau beranda sistem warga. Admin sebagai pengguna tertinggi atau super-user yang mampu 
melakukan semua yang ada di sistem. Mulai dari manipulasi data melihat, menambah, mengedit hingga menghapus data.

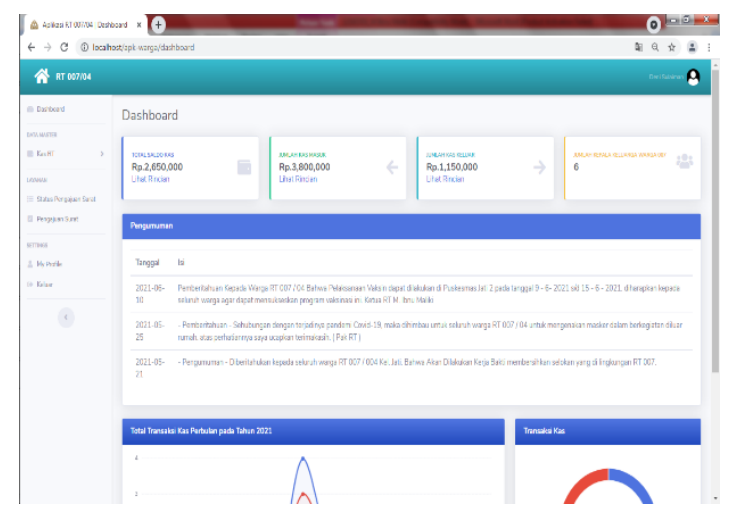

Gambar 7. Dashboard Warga

Gambar 7 merupakan tampilan dashboard atau beranda dari level pengguna warga, setelah berhasil login sistem akan mengarahkan ke beranda. Level pengguna warga hanya dapat melakukan beberapa hal di sistem, seperti mengedit profil, mengajukan surat, hingga keluar dari sistem.

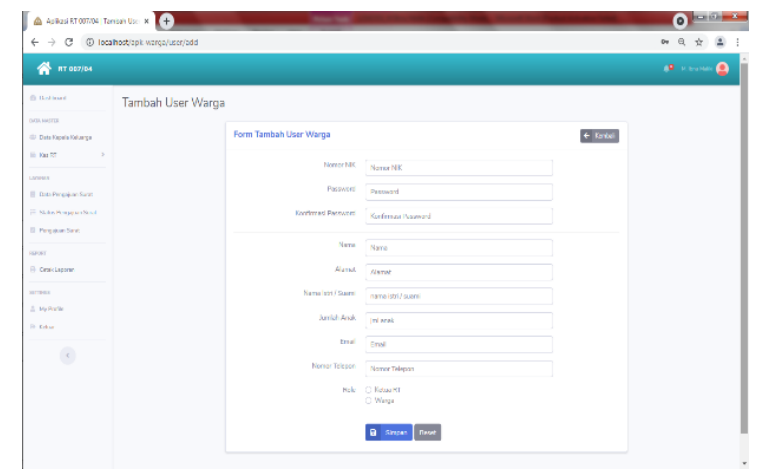

Gambar 8. Form Tambah Data Warga

Gambar 8 adalah antar muka dari form tambah data warga, halaman ini hanya dapat dilakukan pada level admin.

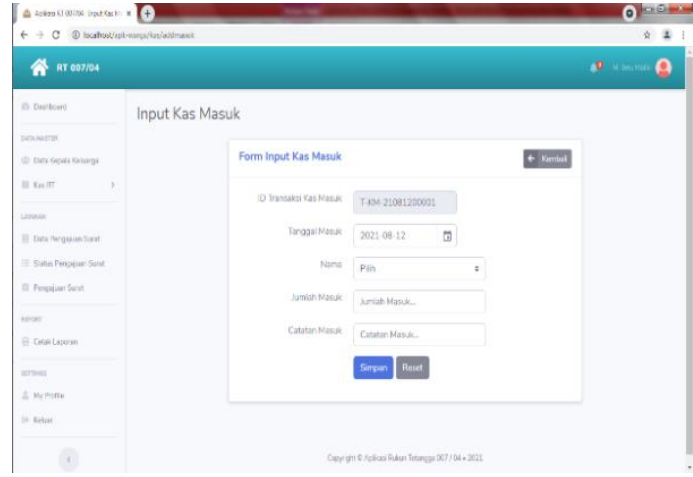

Gambar 9. Antar Muka Kas Masuk

Gambar 9 adalah antar muka kas masuk, dimana hanya level admin yang dapat memanipulasi form ini selaku pengguna tertinggi atau super user pada sistem aplikasi warga.

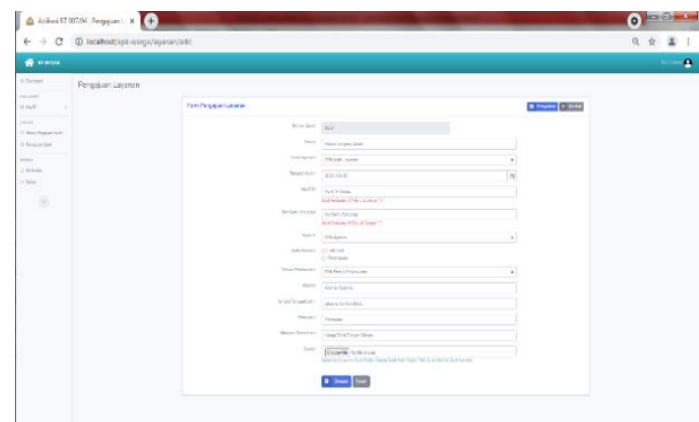

Gambar 10. Antar Muka Pengajuan Surat Gambar 10 adalah antar muka pengajuan surat, jika warga ingin membuat surat pengajuan apapun terkait dengan kepentingan warga, warga dapat mengisi padal laman ini, setelah berhasil login ke sistem. 


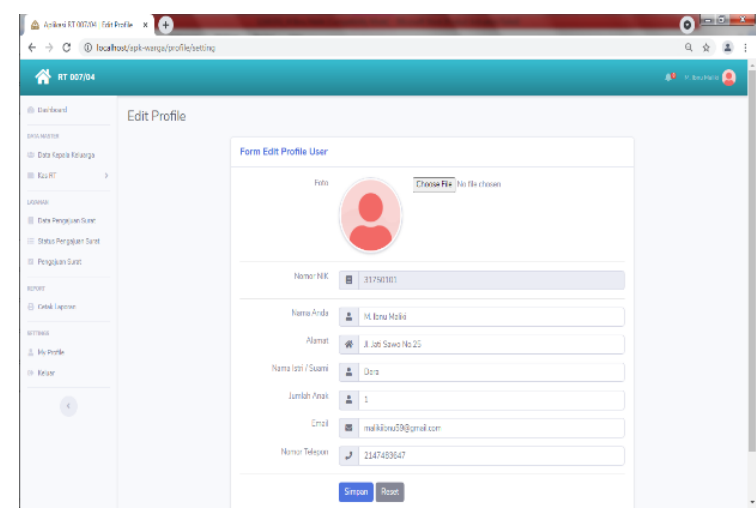

Gambar 11. Antar Muka Edit Profil

Gambar 11 diatas merupakan halaman edit profil, semua level pengguna yaitu admin dan warga, mereka dapat melakukan perubahan pada profilnya pada dashboard masing-masing. Pada kolom NIK tidak dapat dilakukan perubahan, disebabkan factor keamanan dan NIK merupakan kunci utama yang tidak dapat diedit khususnya oleh pengguna di bawah level admin.

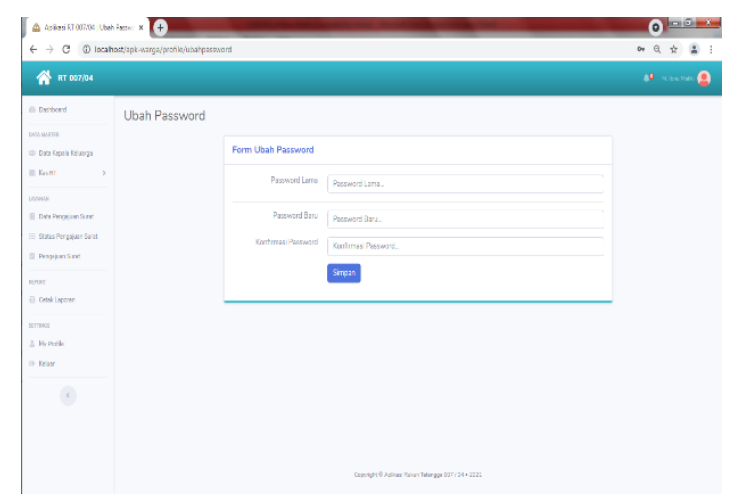

Gambar 12. Antar Muka Ubah Password Gambar pada 12 yaitu antar muka ubah password, untuk mencegah sistem dari pengguna yang tidak berhak, diminta para pengguna melakukan perubahan kata sandi secara berkala demi keamanan. Untuk merubahnya diharapkan menggunakan kata sandi yang mudah diingat dan dihindari mengisi dengan format tanggal lahir.

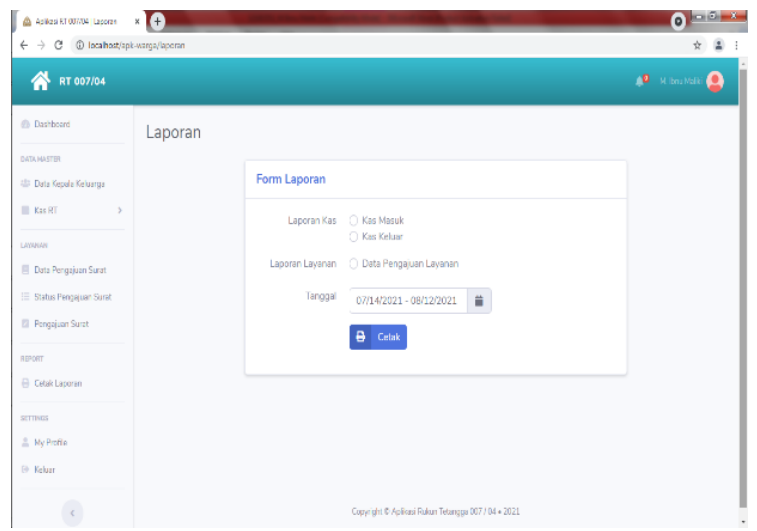

Gambar 13. Antar Muka Cetak Laporan

Gambar 13 adalah antar muka untuk mengolah laporan, admin dapat memilih laporan mana yang ingin dicetak(laporan kas masuk dan keluar atau pengajuan surat) berdasarkan tanggal per periodik.

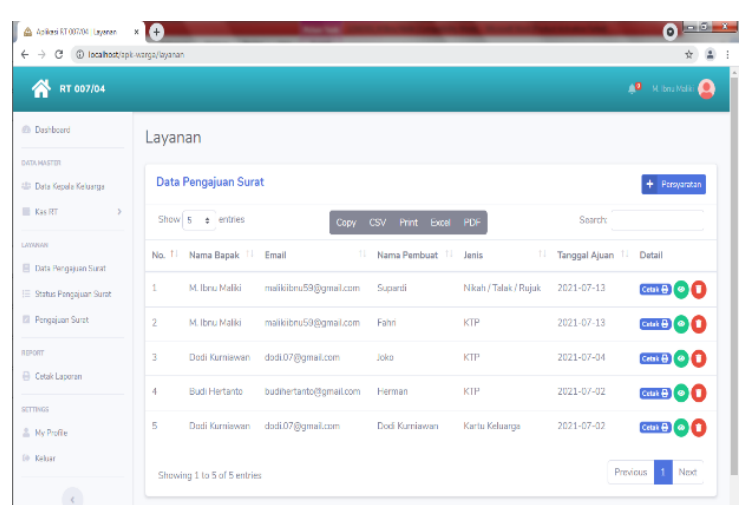

Gambar 14. Antar Muka Data Pengajuan Warga Gambar 14 diatas adalah data pengajuan surat dari tiap warga yang mengajukan surat. Admin dapat melihat semua warga yang melakukan pengajuan surat, admin dapat melihat, mencetak hingga menghapus data pengajuan surat dari warga. 


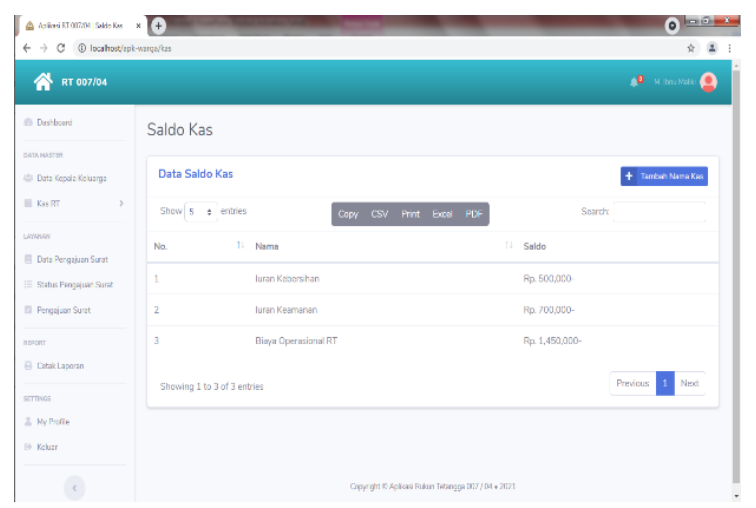

Gambar 15. Antar Muka Data Saldo Kas

Gambar 15 dapat menampilkan data saldo kas warga, manipulasi data juga hanya dapat dilakukan oleh admin.

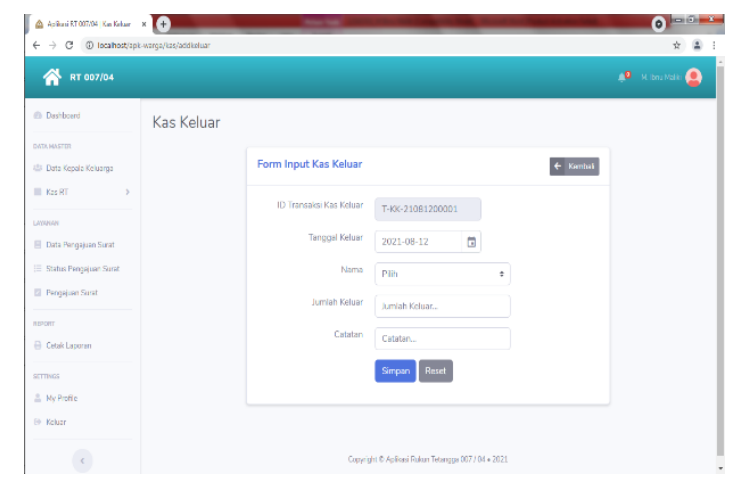

Gambar 16. Antar Muka Tambah Kas Keluar

Gambar 16 merupakan form tambah data transaksi kas keluar, hanya admin yang dapat melakukan manipulasi data di form ini.

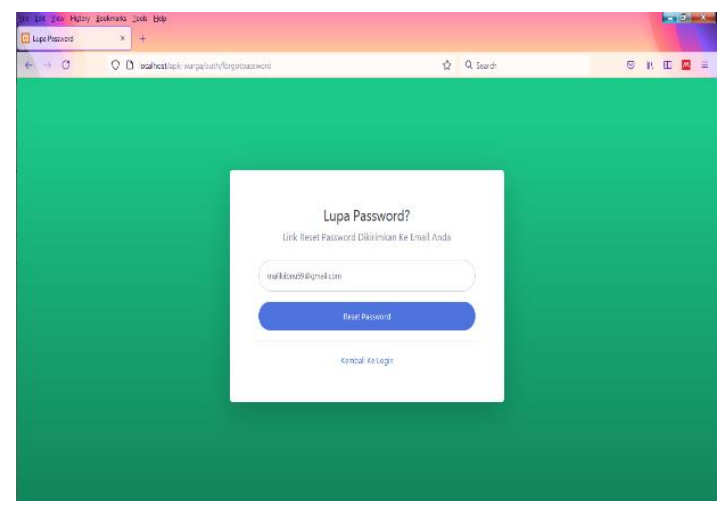

Gambar 17. Antar Muka Lupa Password Pada gambar 17, menjelaskan antar muka lupa kata sandi, jika pengguna atau warga lupa kata sandi, dapat melakukan reset password pada form ini, permintaan akan masuk di panel admin, dan admin akan memberikan tanggapan pengguna melalui surat elektronik pengguna.

Pengujian dan Pergantian

Tiga Metode dan teknik yang biasa dilakukan untuk pengujian aplikasi web(Kappel)[15], antara lain:

\section{a. Tes Browser (Browser Testing)}

Testing Browser digunakan untuk menemukan error pada aplikasi Web yang berakibat tidak cocoknya di multi browser.

1. Tes Web pada Browser Mozilla Firefox 95.0.2 Pengujian menggunakan Browser Mozilla Firefox. Hasilnya ditemukan tidak adanya eror, semua bagian seperti script HTML, PHP, basis data pada mysql dan javascript, berjalan sesuai dengan apa yang diharapkan.

\section{Menggunakan Browser Opera}

Pengujian menggunakan Browser Opera versi 82.0.4227.33 Hasil dari pengujian, tidak ditemukannya kesalahan, semua komponen pun berjalan sesuai dengan apa yang diharapkan.

3. Pengujian dengan Browser Internet Explorer 8.0

Pengujian dilakukan dengan menggunakan Browser Internet Explorer(IE). Hasilny memberikan hasil yang memuaskan, tidak 
ditemukan eror atau kesalahan, semua komponen berjalan dengan baik sesuai dengan apa yang diharapkan.

b. Usabiliy Testing

Usability Testing, yang dilakukan, sebanyak dua pengujian, yaitu:

\section{Pencegahan kesalahan}

Dilakukan untuk mencegah terjadinya kesalahan saat melakukan pemasukan data, seperti data pendaftaran yang biasanya di berikan tanda bintang $\left({ }^{*}\right)$ yang menandakan kolom isian "wajib di isi". Pencegahan dengan javascript seperti kolom nomor telepon yang seharusnya di isi dengan tipe data numerik.

\section{Pemberian Feedback}

Dapat diberikan berupa notifikasi untuk memberikan respon jika terdapat kesalahan penginputan. Dapat berupa window atau jendela tampil dengan pesan eror yang sesuai atau langsung ke kolom inputan. Seperti tampil pada gambar 18 dibawah.

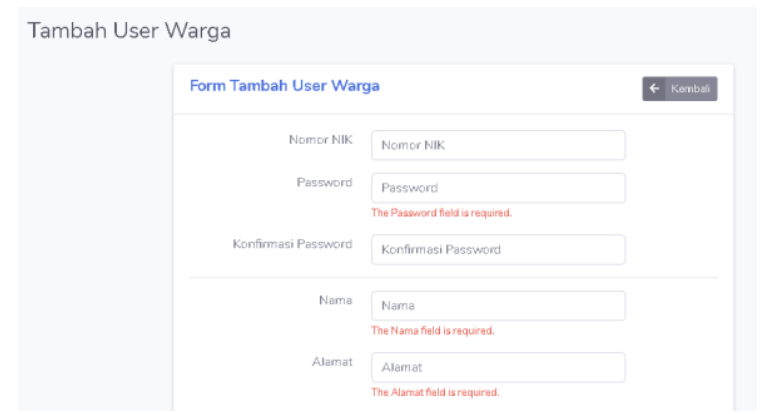

Gambar 18. Notifikasi Kesalahan

\section{c. Security Testing}

Sistem aplikasi wajib memiliki keamanan untuk mencegah akses yang tidak berhak oleh pihak tak bertanggung jawab, terutama jika sistem yang bersifat online. Sederhananya sistem ini dibangun dari framework codeigniter, yang mana sudah menerapkan sistem keamanan yang baik, setiap pengguna jika dalam waktu lama tidak menggunakan aplikasi akan keluar atau logout dari sistem secara otomatis. Dari sistem multi user, sudah dibagi kedalam level pengguna, yang mana tiap pengguna memiliki akses masingmasing ke sistem dan tiap pengguna tidak akan saling mengetahui data pengguna lain, terkecuali admin sebagai super-user sistem. 10 daftar kerentanan yang terdapat di dalam OWASP Top 102017 salah satunya adalah sql injection[16] , contoh: SELECT count (*) FROM Users WHERE Username='alam' AND Password= 'ganteng' , maka penyerang akan melakukan :

SELECT count $\left({ }^{*}\right)$ FROM Users WHERE Username='qwerty' or 1=1 - ' AND Password= 'abcdefg'. Hasilnya setelah dilakukan testing dengan cara diatas, sistem aman dari tindakan tesebut.

\section{Kesimpulan}

Berdasarkan penelitian yang telah dilakukan, bahwa sistem yang dibangun ini menggunakan metode Rapid Application Development dimana metode ini merupakan model proses perangkat lunak yang menekankan kepada pengembangan sistem yang singkat. Sistem yang dibangun juga telah memenuhi kebutuhan tujuan penelitian ini 
diantaranya mempermudah dalam pengajuan surat pengantar, mempermudah warga melihat informasi kas RT, dan mempermudah ketua RT dalam membuat laporan. Pengujian sistem juga telah dilakukan dengan Black Box Testing yang berpusat kepada proses masukkan atau inputan dan pengujian berjalan sesuai harapan yang diinginkan.

\section{Daftar Pustaka}

[1] W. D. Septiani, "Sistem Informasi Pengelolaan Data Penduduk (Studi Kasus: RT/RW Kelurahan Pondok Kacang Timur)," J. Ilmu Pengetah. Dan Teknol. Komput., vol. 4, no. 1, pp. 23-28, 2018.

[2] A. Andie, "Sistem Informasi Dan Administrasi Rt (Sipakrt) Berbasis Web," Technol. J. IIm., vol. 10, no. 3, p. 140, 2019, doi: 10.31602/tji.v10i3.2120.

[3] R. T. Dan, R. W. Berbasis, W. Dengan, and M. Scrum, "Inti nusa mandiri," vol. 15, no. 2, pp. 25-34, 2021.

[4] E. Dewi, S. Mulyani, R. A. Wiyono, and J. T. Informatika, "Sistem Informasi Warga (Simwarga) Tingkat Rt/Rw Berbasis Web," Semin. Nas. Pengabdi. pada Masy., pp. 447454, 2019.

[5] P. Rahardiyanto and Z. Prihandono, "SISTEM INFORMASI PELAYANAN ADMINISTRASI KELURAHAN BERBASIS WEB DENGAN FASILITAS E-COMPLAINT," vol. 13, no. 02, pp. 58-65, 2021.

[6] I. Zamaludin, W. Yusnaeni, and S. Amelia, "Perancangan Pembelajaran Jarak Jauh (ELearning) Bahasa Jerman Berbasis Web," J. PROSISKO Vol., vol. 3, no. 2, pp. 20-25, 2016.

[7] A. Sudianto and M. Wasil, "Penerapan Sistem Informasi Geografis dalam Pemetaan Sebaran Kasus Gizi Buruk Lombok Timur merupakan salah satu Kabupaten yang berada di Provinsi Nusa Tenggara Barat yang terletak di sebelah Timur Pulau Lombok , Kabupaten Lombok Timur Gizi Buruk Malnutrisi," vol. 4, no. 2, pp. 142-150, 2021.

[8] P. Studi, S. Informasi, U. Bina, and S. Informatika, "Peminjaman Dan Pengembalian Buku Perpustakaan Dengan Metode Rapid Application Development Pada SMA Nusantara 1 Tangerang Perpustakaan menjadi wahana fundamental bagi proses pembelajaran. Pada saat pembelajaran kosong karena guru rapat atau berhalangan ha," vol. 4, no. 2, pp. 280-291, 2021.

[9] O. I. - AMIK BSI Bekasi and G. B. A. L. - AMIK BSI Bekasi, "Metode Rapid Application Development (RAD) pada Perancangan Website Inventory PT. SARANA ABADI MAKMUR BERSAMA (S.A.M.B) JAKARTA," Evolusi J. Sains dan Manaj., vol. 6, no. 2, pp. 12-18, 2018, doi: 
10.31294/evolusi.v6i2.4414.

[10] T. Pricillia and Zulfachmi, "Perbandingan Metode Pengembangan Perangkat Lunak," Surv. Pap., vol. X, no. 01, pp. 6-12, 2021.

[11] S. Suhartini, M. Sadali, and Y. Kuspandi Putra, "Sistem Informasi Berbasis Web Sma Al- Mukhtariyah Mamben Lauk Berbasis Php Dan Mysql Dengan Framework Codeigniter," Infotek J. Inform. dan Teknol., vol. 3, no. 1, pp. 79-83, 2020, doi: 10.29408/jit.v3i1.1793.

[12] I. Gunawan, H. Ahmadi, and M. R. Said, "Rancang Bangun Sistem Monitoring Dan Pemberi Pakan Otomatis Ayam Anakan Berbasis Internet Of Things (loT)," Infotek J. Inform. dan Teknol., vol. 4, no. 2, pp. 151162, 2021, doi: 10.29408/jit.v4i2.3562.

[13] E. Widyawati, "Rancang Bangun Aplikasi Kependudukan Berbasis Web Di Desa Kedungrejo Waru-Sidoarjo," J. Manaj.
Inform., vol. 6, no. 1, 2016.

[14] R. A. Sukamto and M. Shalahuddin, Rekayasa Perangkat Lunak Terstruktur dan Berorientasi Objek, 4th ed. Bandung: Informatika, 2016.

[15] Frieyadie, "Model Rapid Application Development Untuk Rancang Bangun Sistem Informasi Tempat Pemakaman Umum," J. Ilmu Pengetah. dan Teknol. Komput., vol. 2, no. 2, pp. 7-14, 2017.

[16] S. Hidayatulloh and D. Saptadiaji, "Penetration Testing pada Website Universitas ARS Menggunakan Open Web Application Security Project (OWASP)," J. Algoritm., vol. 18, no. 1, pp. 77-86, 2021, doi: 10.33364/algoritma/v.18-1.827. 